\title{
Analysis and assessment of the level of biological risks of activities of enterprises of the agro-industrial complex at the regional level
}

\author{
Alexandr Shemyakin ${ }^{1}$, Yuliya Lyashchuk $^{2}$, Alexey Martynushkin ${ }^{1, *}$, Konstantin \\ Ivanishchev $^{1}$, Elena Strokova $^{1}$, and Alexandr Krasnikov ${ }^{1}$ \\ ${ }^{1}$ Ryazan State Agrotechnological University Named after P.A. Kostychev, Ryazan, Russia \\ ${ }^{2}$ Moscow University named after S.Y. Witte (Ryazan branch), Ryazan, Russia
}

\begin{abstract}
The article discusses the relevance of analyzing the level of biological risks from the point of view of activities of enterprises of the agro-industrial complex. Agro-industrial complex enterprises deal with living organisms (plants and animals), characterized by a development cycle closely related to natural and climatic conditions, and subordination to the biological laws of the functioning of living things. This is the reason for risks being specific only to this industry (biological, climatic, risks of seasonality of production, etc.). Biological risks are the undisputed leaders in this list, since they pose a threat to the life and health of people when using the products of agricultural enterprises. The authors consider biological threats of human infection when eating livestock products, since (unlike plants) humans and animals have a common group of diseases called zooanthroponosis. The analysis of studies and opinions of specialists in veterinary and sanitary examination, microbiology, epizootology, infectious diseases and epidemiology allowed to compile a list of biological risk factors, identify criteria for assessing the degree of risk, and conduct their quantitative and qualitative assessment at the regional level.
\end{abstract}

\section{Introduction}

The realities of the modern world reflect the tendency of a shift in priorities in the development of new types of weapons of mass destruction from nuclear and climate weapons towards biological weapons. And there are reasons for this.

Biological weapons have a number of significant advantages over both climate and nuclear weapons and traditional types of weapons. These advantages include:

1 - high efficiency of application with minimal damage to infrastructure and the environment;

2 - a wide variety of pathogens of infectious and parasitic diseases that can be used for military purposes;

* Corresponding author : kosta066@yandex.ru 
3 - the fact of the use of biological weapons is extremely difficult to prove and timely detect due to an incubation period and a self-sustaining mechanism of epidemiological damage;

4 - a variety of ways and factors of transmission of pathogens: fecal-oral mechanism: alimentary, water and contact-household transmission routes; vertical mechanism: transplacental and transovarian transmission routes; aerogenic mechanism: airborne and airdust transmission routes; contact mechanism: contact (wound, contact-sexual) transmission route; transmission (blood) mechanism: transmission route);

5 - the possibility of cross-contamination of humans and animals;

6 - strong psychological impact on the population (panic and fear).

Both anthroponosis and zooanthroponosis can be used as biological weapons. Zooanthroponosis is dangerous because people can become infected from animals not only through direct contact (in this case, mainly specialists working with animals and animal products are at risk), but also through food (and in this case, all categories of the population are at risk).

The spread of pathogens through food is quite effective, since the possibility of distinguishing a planned infection of the population from a spontaneous (natural) one is small.

\section{Materials and methods}

To analyze the level of biological risk at the regional level, the collection and analysis of information on the epidemiological and epizootic situation in the region or regions where the enterprise directly operates is carried out. The results of the risk analysis at this level are applicable for the use of agricultural enterprises in the region.

Analysis and assessment of the regional level of biological risk was carried out for enterprises of the agro-industrial complex of Ryazan region.

Analysis and assessment of risk at the regional level includes 3 stages:

1 - Analysis and assessment of the epidemiological level of risk.

2 - Analysis and assessment of the epizootic level of risk.

3 - Analysis and assessment of the regional level of risk.

When analyzing the information and selecting pathogens, not only the alimentary (food) transmission route was considered, but also the hazard factor and the preva-lence of caused diseases.

The list includes risk factors of various etiologies:

- bacterial etiology: Mycobacterium tuberculosis, M. bovis, M. avium, bacteria of genus Campylobacter (C. coli, C. jejuni, C. intestinalis, C. upsaliensis, C. lari, C. fetus, C. sputorum), Brucella (B. abortus, B. melitensis, B. suis), Leptospira (L. icterohaemorrhagiae, L. canicola, L. hebdomadis, L. grippothyphosa, L. tarassovi, L. pomona), Shigella (S. dysenteriae, S. boydii, S.flexneri, S. sonnei), Escherichia (diarrhoeagenicserovars E. coli), CGB (Klebsiella, Enterobacter, Citrobacter, Serratia), Salmonella (S. newport, S. agona, S. typhimurium S. infantis, S. enterica, S. derby, S. enteritidis, S. london S. typhi, S. paratyphi A, B), Yersinia (Y. enterocolitica, Y. pseudotuberculosis), Vibrio (V. parahaemolyticus, V. cholerae, V. vulnificus), Proteus (P. vulgaris, P. mirabilis), Listeria monocytogenes, Francisellatularensis, Staphy-lococcus aureus, Clostridium botulinum (types A, B, C, D, E, F), Clostridium perfringens (types A, C, D), Bacillus cereus;

- viral etiology: foot and mouth disease virus, hepatitis A virus, viruses of Rotavirus genus of Reoviridae family, Norwalk virus of Norovirus genus of Caliciviridae fami-ly;

- protozoal etiology: Entamoebahistolytica, Toxoplasma gondii, Lamblia (Giardia) intestinalis, Cryptosporidium parvum; 
- helminthic etiology (Taeniarhynchussaginatus, Taeniasolium, Hymenolepisnana, helminths of subfamily Echinococcine (E. granulosus, E. multilocularis), helminths of genus Diphyllobothrium (D. Latum), Opisthorchis (O. felineus и O. viverrini), Fasciola (F. hepatica и F. gigantica), Trichinella (Т. spiralis, T. pseudospiralis), Asca-rislumbricoides, Trichocephalustrichiuris (Trichuristrichiura), Enterobiusvermicularis.

Thus, the list includes 16 risk factors for bacterial etiology, of which $31.25 \%$ are causative agents of especially dangerous infections (tuberculosis, brucellosis, tulare-mia, listeriosis and leptospirosis) and $68.75 \%$ are causative agents of acute intestinal infections (AII), which are widespread all over the world and annually claim the lives of hundreds of thousands of people.

A quantitative assessment of biological risk factors for epidemiological indicators of infectious morbidity in Ryazan region for 5 years is presented in Table 1.

Table 1. Quantitative assessment of biological risk factors by epidemiological indicators of infectious morbidity.

\begin{tabular}{|c|c|c|}
\hline \multirow{2}{*}{ Risk factor } & \multicolumn{2}{|c|}{ Risk level } \\
\hline & Grades & Group \\
\hline Taeniasolium & 0.39 & \\
\hline Entamoebahistolytica & 0.40 & \multirow{9}{*}{ Very low } \\
\hline Strongyloidesstercoralis & 0.40 & \\
\hline Helminths of genus Trichinella & 0.78 & \\
\hline Taeniarhynchussaginatus & 0.79 & \\
\hline Helminths of genus Diphyllobothrium & 0.79 & \\
\hline Toxoplasma gondii & 1.18 & \\
\hline Trichocephalustrichiuris & 1.18 & \\
\hline Bacteria of genus Yersinia & 1.57 & \\
\hline Bacteria of genus Leptospira & 8.25 & \\
\hline Bacteria of genus Campylobacter & 12.37 & \multirow{3}{*}{ Low } \\
\hline Helminths of genus Opisthorchis & 16.073 & \\
\hline Francisellatularensis & 17.358 & \\
\hline Helminths of subfamily Echinococcine & 61.56 & \multirow{3}{*}{ Medium } \\
\hline Bacteria of genus Shigella & 74.292 & \\
\hline Bacteria of genus Proteus & 87.92 & \\
\hline Virus Norwalk & 104 & \multirow{3}{*}{ High } \\
\hline Ascarislumbricoides & 130.819 & \\
\hline Virus of hepatitis A & 163.99 & \\
\hline Staphylococcus aureus & 365.572 & \multirow{7}{*}{ Very high } \\
\hline Diarrhoeagenic E. coli and CGB & 367.23 & \\
\hline Bacteria of genus Salmonella & 371.161 & \\
\hline Virus of genus Rotavirus & 515.665 & \\
\hline Enterobiusvermicularis & 1221.103 & \\
\hline Lamblia (Giardia) intestinalis & 1224.498 & \\
\hline M. tuberculosis, M. bovis, M. avium & 1481.492 & \\
\hline
\end{tabular}

The risk assessment was carried out according to the following criteria:

1) The incidence in the reporting year (2020) and for the period (total for 2016-2020):

1 grade is 10 people in absolute numbers $(\mathrm{K}), 1$ person per 100 thousand population $(\mathrm{P})$;

2) Morbidity dynamics for the reporting year and the year preceding the reporting year (2019-2020) and for the period (2016-2020):

0 grade stands for a decrease in the indicator;

1 grade stands for 5 people in absolute numbers (K), 1 person per 100 thousand population (P) for "+/-"; 
1 grade stands for $10 \%$ (a single indicator, the calculation is based on the largest percentage);

30 grades mean an outbreak of morbidity, marked as "-".

The epidemiological level of risk is characterized by the following scale:

up to 10 grades mean a very low risk level;

11-50 grades mean a low risk level;

51-100 grades mean a medium risk level;

101-200 grades mean a high risk level;

more than 200 grades mean a very high risk level.

As the analysis of the table shows, diseases caused by 10 (27.78\%) of the 36 biological risk factors are not registered in Ryazan region are not registered, $27.78 \%$ have a very low level of risk, $8.33 \%$ have a low level of risk, $8.33 \%$ have a medium level of risk, 8.33 $\%$ have a high level of risk and $19.44 \%$ have a very high level of risk.

Mycobacterium tuberculosis has the highest level of epidemiological risk (Lepid = 1,481.492). Causative agents of giardiasis (Lepid $=1,224.498)$ and enterobiasis (Lep-id $=$ $1,221.103$ ) have an almost equal level of risk. An anxiety level is caused by causative agents of rotavirus infection (Lepid $=515.665$ ). Causative agents of acute intestinal infections also have a similar and rather high level of epidemiological risk, which has a range from 365.572 to 371.161 for causative agents of staphylococcosis (Lepid = 365.572), escherichiosis $($ Lepid $=367.230)$ and salmonellosis $($ Lepid $=371.161)$.

A quantitative assessment of biological risk factors for epizootic indicators of infectious morbidity in Ryazan region for 5 years is presented in Table 2.

The risk assessment was carried out according to the following criteria:

1) Morbidity in the reporting year (2020) and for the period (total for 2016-2020):

1 grade means 10 animals.

Rating scale:

2 grades stand for SH (number of sick heads);

1.5 grades - D (the number of reactive heads when diagnostic studies);

1 grade stands for VSE (revealed as a result of veterinary examination of slaughtered animals and veterinary and sanitary examination of products);

2) Morbidity dynamics for the reporting year and the year preceding the reporting year (2019-2020), and for the period (2016-2020):

0 grade stands for a decrease in indicator;

1 grade stands for 5 animals for " $+/$-";

1 grade means $10 \%$;

30 grades mean an outbreak of morbidity, marked as "-".

The epizootic level of risk is characterized by the following scale:

up to 10 grades mean a very low risk level;

11-50 grades mean a low risk level;

51-100 grades mean a medium risk level;

101-200 grades mean a high risk level;

more than 200 grades mean a very high risk level.

Table 2. Quantitative assessment of biological risk factors by epizootic indicators of infectious morbidity.

\begin{tabular}{|c|c|c|c|c|}
\hline \multirow[b]{2}{*}{ Risk factor } & \multirow[b]{2}{*}{ Disease } & \multirow{2}{*}{ Animals } & \multicolumn{2}{|c|}{ Risk level } \\
\hline & & & Grades & Group \\
\hline $\begin{array}{l}\text { Helminths of genus } \\
\text { Trichinella }\end{array}$ & Trichinosis & Pigs & 0.5 & Very \\
\hline Bacteria of genus Proteus & $\begin{array}{l}\text { PTI caused by } \\
\text { Proteus }\end{array}$ & Cattle & 0.8 & low \\
\hline Taeniarhynchussaginatus & Cysticercosis & Cattle & 16.85 & Low \\
\hline
\end{tabular}




\begin{tabular}{|c|c|c|c|c|}
\hline & (measles) & & & \\
\hline \multirow{3}{*}{$\begin{array}{l}\text { Bacteria of genus } \\
\text { Salmonella }\end{array}$} & \multirow{3}{*}{ Salmonellosis } & Cattle & \multirow{3}{*}{33.63} & \\
\hline & & Pigs & & \\
\hline & & All kinds & & \\
\hline Taeniasolium & $\begin{array}{l}\text { Cysticercosis } \\
\text { (measles) }\end{array}$ & Pigs & 36.13 & \\
\hline \multirow{4}{*}{$\begin{array}{l}\text { Bacteria of genus } \\
\text { Escherichia (diarrhoeagenic } \\
\text { E. coli) }\end{array}$} & \multirow{4}{*}{ Colibacillosis } & Cattle & \multirow{4}{*}{143.5} & \multirow{4}{*}{ High } \\
\hline & & MPC & & \\
\hline & & Pigs & & \\
\hline & & Poultry & & \\
\hline \multirow{3}{*}{$\begin{array}{l}\text { Bacteria of genus } \\
\text { Leptospira }\end{array}$} & \multirow{3}{*}{ Leptospirosis } & Cattle & \multirow{3}{*}{206.7} & \multirow{5}{*}{$\begin{array}{l}\text { Very } \\
\text { high }\end{array}$} \\
\hline & & Horses & & \\
\hline & & All kinds & & \\
\hline Staphylococcus aureus & $\begin{array}{l}\text { Mastitis caused by } \\
\text { staphylococcus }\end{array}$ & Cattle & 388.48 & \\
\hline $\begin{array}{l}\text { M. tuberculosis, } \\
\text { M. bovis, } \\
\text { M. avium }\end{array}$ & Tuberculosis & Cattle & 745.97 & \\
\hline
\end{tabular}

\section{Results and discussion}

As the analysis of the table shows, only 9 out of 36 considered biological risk factors are zooanthroponosis being important for risk analysis in Ryazan region, of which $22.22 \%$ have a very low level of risk, $33.33 \%$ have a low level of risk, $11.11 \%$ have a high level of risk and $33.33 \%$ have a very high risk level.

Mycobacterium tuberculosis (Lepiz $=745.97)$, bacteria of Staphylococcus aureus (Lepiz $=388.48)$ and diarrhoeagenicserovars of Escherichia $($ Lepiz $=143.5)$ have the highest level of the epizootic risk.

To assess the regional level of risk, it is necessary to sum the grades for the epidemiological and epizootic levels (Table 3).

The regional level of biological risk is characterized by the following scale:

up to 20 grades mean a very low risk level;

21-100 grades mean a low risk level;

101-200 grades mean a medium level of risk;

201-400 grades mean a high level of risk;

more than 400 grades mean a very high level of risk.

Table 3. Quantitative assessment of biological risk factors at the regional level for enterprises of the agro-industrial complex of Ryazan region.

\begin{tabular}{|l|c|c|}
\hline \multirow{2}{*}{ Risk factor } & \multicolumn{2}{c|}{ Risk level } \\
\cline { 2 - 2 } & Grades & \multirow{2}{*}{ Group } \\
\hline Strongyloidesstercoralis & 0.40 & \multirow{2}{*}{} \\
\hline Entamoebahistolytica & 0.40 & \\
\hline Helminths of genus Diphyllobothrium & 0.79 & \multirow{2}{*}{ Very low } \\
\hline Trichocephalustrichiuris & 1.18 & \\
\hline Toxoplasma gondii & 1.18 & \\
\hline Helminths of genus Trichinella & 1.28 & \\
\hline Bacteria of genus Yersinia & 1.57 & \\
\hline Bacteria of genus Campylobacter & 12.37 & \\
\hline Helminths of genus Opisthorchis & 16.073 & \\
\hline Francisellatularensis & 17.358 & \multirow{2}{*}{ Low } \\
\hline Taeniarhynchussaginatus & 17.64 & \\
\hline Taeniasolium & $\mathbf{3 6 . 5 2}$ & \\
\hline
\end{tabular}




\begin{tabular}{|l|c|c|}
\hline Helminths of subfamily Echinococcine & 61.56 & \multirow{2}{*}{ Medium } \\
\hline Bacteria of genus Shigella & 74.292 & \\
\hline Bacteria of genus Proteus & 88.72 & \\
\hline Virus Norwalk & 104 & \multirow{2}{*}{ High } \\
\hline Ascarislumbricoides & 130.819 & \\
\hline Virus of hepatitis A & 163.99 & \\
\hline Bacteria of genus Leptospira & 214.95 & \multirow{2}{*}{ Very high } \\
\cline { 1 - 2 } Bacteria of genus Salmonella & 404.791 & \\
\hline Bacteria of genus Escherichia & 510.73 & \\
\hline Virus of genus Rotavirus & 515.665 & \\
\cline { 1 - 2 } Staphylococcus aureus & 754.052 & \\
\cline { 1 - 2 } Enterobiusvermicularis & $1,221.103$ & \\
\cline { 1 - 2 } Lamblia (Giardia) intestinalis & $1,224.498$ & \\
\cline { 1 - 2 } M. tuberculosis, M. bovis, M. avium & $2,227.462$ & \\
\hline
\end{tabular}

\section{Discussion}

As the analysis of the table shows, in accordance with the epidemiological and epizootic situation in Ryazan region, 26 of the 36 biological risk factors are of analytical interest, of which $42.31 \%$ have a very low level of risk, $15.38 \%$ have a low level of risk, $11.54 \%$ have a medium level of risk, $3.85 \%$ have a high level of risk and $26.92 \%$ have a very high level of risk.

As the analysis shows the highest level of biological risk is in bacteria of genera Leptospira, Salmonella, Escherichia, Staphylococcus aureus, bacteria of the E. coli group, M. tuberculosis, M. bovis, M. avium, viruses of genus Rotavirus, Enterobiusvermicularis and Lamblia (Giardia) intestinalis.

Taeniarhynchussaginatus, Taeniasolium, bacteria of genera Leptospira, Salmonella, Escherichia, bacteria of E. coli group, Staphylococcus aureus and mycobacterium tuberculosis (M. tuberculosis, M. bovis, M. avium) affect the level of cross-infection and have a clearly visible dependence of morbidity of people and animals. For these risk factors, it is recommended to conduct a correlation analysis of the dependence of the epidemiological and epizootic levels of risk with the construction of graphical models of the dynamics of biological risk.

\section{Conclusion}

In conclusion, it should be noted that risk factors of bacterial etiology are the most dangerous ones. As the analysis showed, mycobacterium tuberculosis (Lepid $=1,481.492$, Lepiz $=745.97)$, bacteria of Staphylococcus aureus $($ Lepid $=365.572$, Lepiz $=388.48)$, diarrheogenicserovars of Escherichia and bacteria of Escherichia coli group (Lepid = 367.230, Lepiz $=143.5)$ and various serovars of Salmonella $($ Lepid $=371.161$, Lepiz $=$ 33.63) most significantly affect the level of cross-contamination and have a clearly visible correlation between the incidence of humans and animals.

From the point of view of biological hazard, food toxicoinfections and acute intestinal infections are promising, since their pathogens are transmitted by the alimentary (food) route, and their use as a biological weapon can provide a fairly rapid and massive infection through food for all categories of the population. At the same time, determining the primary source and predicting the path of further propagation is a rather complicated and timeconsuming process, with a large share of probabilistic error. And if it is still possible to predict the spread of infection from the outbreak with rather high accuracy thanks to modern information technological means, then it is rather difficult to determine whether the 
cause of the outbreak of infection is natural or artificial, it is even more difficult to prove that mass infection of people is a deliberate act, and not a coincidence.

From the point of view of mass spread, infections transmitted by contact-household and airborne droplets are also promising. They provide a fairly wide area of damage, coupled with the difficulty of identifying the source of infection (one sneezing passenger in public transport is enough for everyone present to inhale the infected aerosol and carry the infection inside in a variety of random and sometimes illogical directions). The situation is similar with contact-household transmission. It is enough to leave the environment with the pathogen in a public place (for example, walking in the autumn-winter period with your hands in contaminated leather gloves along the escalator handrails or handrails in transport). Everyone who is unlucky enough to be in the zone of primary infection will carry the infection on themselves and then in themselves further. Given the presence of the incubation period and the time required for further transmission, it is extremely difficult to identify the exact time of a biological attack. More often it is possible only to establish an approximate interval (up to a day) and the place of distribution. Revealing the rest of details requires a "hot pursuit" response, that is a priori impossible (for example, in public transport without surveillance cameras, especially in the rush hour in a crowd), since from the start of the event to the start of the response in an emergency mode, it takes too long to clear the information traces.

Summing up, it must be said that in modern conditions it is more important than ever to track the results of monitoring infectious diseases and have a rapid response system, not only for highly specialized medical institutions, but also for food industry and public catering enterprises.

\section{References}

1. A.B. Martynushkin, Yu.B. Kostrova, Yu.O. Lyashchuk, Bulletin of KrasGAU 9(162), 157-164 (2020)

2. V.S. Konkina, A.B. Martynushkin, International Transaction Journal of Engineering, Management and Applied Sciences and Technologies 11(10), 11A10L (2020)

3. A.B. Martynushkin, V.S. Konkina, J.B. Kostrova et al, Modern Trends in Agricultural Production in the World Economy, 77-84 (2020)

4. A.B. Martynushkin, Yu.B. Kostrova, Yu.O. Lyashchuk, Bulletin of KrasGAU 9(162), 157-164 (2020)

5. A.S. Emelyanova, L.G. Kashirina, E.E. Stepura et al, BIO Web of Conferences 2019 17, 00095 (2020)

6. L.G. Kashirina, K.A. Ivanishchev, K.I. Romanov, BIO Web of Conferences 17, 00096 (2019)

7. V. Konkina, BIO Web of Conferences 17, 00086 (2019)

8. I.Yu. Bystrova, O.A. Fedosova, G.V. Ulivanova et al, International Journal of Advanced Biotechnology and Research 10(2), 392-405 (2019)

9. G.M. Tunikov, I.Yu. Bystrova, N.G. Byshova et al, International Journal of Advanced Biotechnology and Research 10(2), 465-473 (2019)

10. A.S. Emelyanova, L.G. Kashirina, S.D. Emelyanov et al, IOP Conference Series: Earth and Environmental Science 422(1), 012068 (2020)

11. V. Khripin, V. Ulyanov, A. Kiryanov, et al, E3S Web of Conferences 175, 03005 (2020)

12. L. Kashirina, K. Ivanischev, K. Romanov, E3S Web of Conferences 176, 02001 (2020) 
13. I. Kondakova, E. Vologzhanina, J. Lomova, N. Kryuchkova, E3S Web of Conferences: International Scientific and Practical Conference «Development of the Agro-Industrial Complex in the Context of Robotization and Digitalization of Production in Russia and Abroad» 222, 02013 (2020)

14. N.B. Guber, N.I. Morozova, M.V. Eliseenkova et al, IOP Conference Series: Earth and Environmental Science 613(1), 012044 (2020)

15. I.A. Stepanova, A.A. Nazarova, M.V. Arisov, World's Veterinary Journal 10(4), 492498 (2019)

16. M.N. Britan, E.V. Gerceva et al, International Journal of Pharmaceutical Research 11(1), 1040-1048 (2019) 